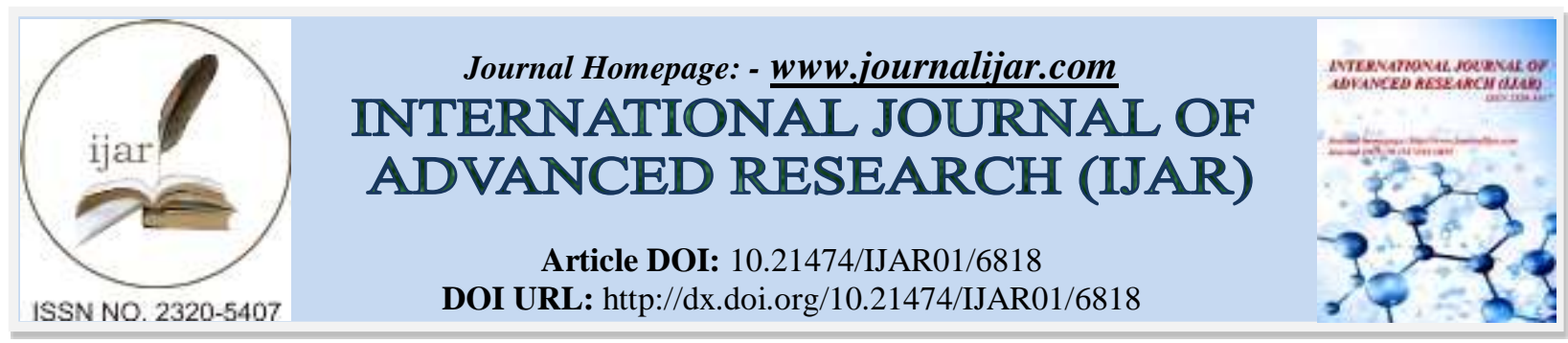

RESEARCH ARTICLE

\title{
SELECTIVE EXCAVATION: A PARADIGM SHIFT IN CARIOUS LESION MANAGEMENT.
}

Dr. Shailaja Datta ${ }^{1}$ and Dr. Suprabha B. $S^{2}$.

1. Post-Graduate Student, Department of Paedodontics and Preventive Dentistry, Manipal College of Dental Sciences, Manipal Academy of Higher Education, Mangalore.

2. Professor, Department of Paedodontics and Preventive Dentistry, Manipal College of Dental Sciences, Manipal Academy of Higher Education, Mangalore.

\section{Manuscript Info}

\section{Manuscript History}

Received: 22 January 2018

Final Accepted: 24 February 2018

Published: March 2018

Keywords:-

Dental caries, dental restoration, tooth

demineralization, composite resin.

\section{Abstract}

With increase in our present day knowledge of the caries process, as driven by the plaque biofilm, the modality of treatment has changed from complete excavation to just providing an adequate restoration. The review intends to highlight the paradigm shift in concepts related to management of deep carious lesions.

Copy Right, IJAR, 2018,. All rights reserved.

\section{Introduction:}

Dental caries is currently understood as the resultant disease which occurs due to an ecologic shift within the dental biofilm, leading to a more acidogenic and aciduric bacterial population. This type of cariogenic microbial population is sustained by frequent intake of fermentable dietary carbohydrates by the host. The outcome is an imbalance between the processes of demineralization and remineralisation, which causes an overall mineral loss from the hard tissues. The signs and symptoms, so developed, are referred to as a carious lesion (Fejerskov et al. 2015). A deep caries lesion may be defined as a lesion where the demineralized dentin has penetrated two-third or three-fourth or more of the entire dentin thickness, radio-graphically .(Gruythuysen et al, 2010; Bjorndal et al,2008)

Over the years, 'extension for prevention' approach has been replaced by a more conservative one. Contemporary cavity preparation includes removal of caries from the periphery of the lesion, while only the infected dentin is removed pulpally. However, this approach to management of carious teeth has a number of consequences. (Ricketts et al,2013).A tooth that entered the cycle of restorations is subjected to restoration failure over a period of time, raising the need for re-restorations. This eventually weakens the tooth structure and often also leads to caries in adjacent teeth. Cavity preparation and restoration reduces the remaining dentin thickness, which is considered to be the most critical factor affecting pulpal health.(Murray et al,2003). Also, studies have shown that children better accept hand excavation without the use of local anaesthetic as less discomfort and pain is associated with the same. (van Bochove et al., 2006)

Considering the consequences of operative treatment and keeping in mind the dynamic nature of caries process, it was suggested that it should be sufficient to seal the lesion adequately causing disturbance within the biofilm, instead of aiming at removing the entire infected dentin. The focus has since shifted from completely excavating the carious dentin to just maintaining an adequately sealed lesion. (Kidd, 2004). The article aims to review the literature 
regarding concepts in selective caries excavation technique and restorations carried out after selective caries excavation.

\section{Selective Excavation Technique for Deep Dentinal Caries:}

The various current treatment approaches for deep dentinal carious lesions include step-wise excavation, selective excavation, and ultra-conservative excavation. Other techniques for management of deep carious lesions include Hall technique and atraumatic restorative treatment.(Ricketts et al, 2013)

Step-wise excavation is the two step removal of caries from a deep carious lesion. (Schewendicke et al,2015).The first step involves incomplete removal of carious tissue, leaving a thin layer of leathery and considerably soft dentin in close proximity to the pulp so as to avoid the risk of pulp exposure.(Schewendicke et al,2015; Bjorndal et al, 2008). The cavity is then sealed with a provisional restoration. In the second visit, 6-8 months later, the lesion is reentered (Rebeiro et al,2012). Any remaining soft caries is now excavated till dry, hard dentin is encountered, and a permanent (adhesive) restoration is provided. Questioning the need for a two-step excavation of deep carious lesions, some authors suggested that such lesions can be managed by a single step incomplete removal of caries. (Kidd, 2004). This approach of incomplete caries excavation in a single visit followed by placement of a permanent restoration in the same visit was referred to as partial caries excavation. Various authors have explored the idea of sealing an active carious lesion under a restoration, without any caries excavation referred to as ultra-conservative caries excavation. The materials used to seal such lesions are diverse: ranging from pit and fissure sealants for sealing pit and fissure caries, amalgam, composite restorations to more novel techniques like use of stainless steel crowns(Kidd, 2004; Mertz-Fairhurst et al,1987; Handelman et al, 1976;Hesse et al, 2014).

The amount of caries removed in partial caries removal, remained subjective to the operator discretion with various authors providing varied descriptions. One of the earliest studies related to partial caries removal was by Rebeiro et al. (1999). The excavation protocol was such that soft, carious dentin was intentionally left at the pulpal and axial wall of primary molars, avoiding any chance of pulp exposure; while complete caries removal was done along the dentino-enamel junction and the cavity margins were clear. In another study, Lula et al (2009) performed a randomized controlled trial to compare the micro flora present under composite restorations performed after partial caries excavation and complete caries removal. Partial caries excavation in this study involved complete removal of necrotic dentin from the periphery of the cavity while the soft dentin in centre of lesion was only removed superficially. This is similar to the excavation protocol followed by Lula et al(2011) where in partial caries removal was such that all carious tissue was removed from the lateral walls of the cavity, whereas carious dentin on pulpal wall was removed superficially. Phonghanyudh et al (2012) performed selective excavation in primary molars, with complete removal of soft caries up to the dentino-enamel junction. Maltz et al (2013) performed partial caries removal in permanent molar teeth. Access was gained to the cavity and following complete caries removal from the walls of the cavity using low speed burs or hand excavators, only the disorganized dentin was hand excavated from cavity floor. Franzon et al.(2014) compared the outcomes of complete versus partial caries removal in primary molar teeth. Complete caries excavation was performed on lateral walls of the cavity and confirmed using a blunt-tipped probe, whereas in partial caries excavation, caries excavation was stopped when hardened, dried dentin with a leathery consistency was achieved.

In 2015, the International Caries Consensus Collaboration (ICCC), which consisted of 21 cariology experts from 12 nations, published a report to reach a consensus on the recommendations and the terminologies related to carious tissue management (Innes et al, 2016).

Selective removal to soft dentine in deep lesions refers to leaving behind soft carious tissue in the pulpal aspect of the cavity, while the peripheral enamel and dentine should be hard at the end of excavation to allow bonding to the restorative material. Previously, this term was referred to as partial caries, one-step, ultraconservative, or incomplete caries removal (Innes et al, 2016).

For deep carious lesions (that is lesions extending into pulpal third or quarter of dentin radio graphically) in teeth with vital, asymptomatic pulp, selective removal to soft dentin should be carried out. This is applicable for both primary and permanent teeth. Soft carious dentin is left over the pulp to avoid any pulpal exposure while the peripheral enamel and dentin are cleared so as to provide an effective seal of a durable restoration. To assess the dentin remaining after caries removal, following recommendations have been laid down: Hardness of dentin should 
be the primary criterion (e.g., soft, leathery, firm or scratchy, or hard) for assessing and describing the carious tissue, moisture (wet, moist, or dry) and colour of dentin (pale/yellow, dark brown/black). (Innes et al, 2016).

Irrespective of the amount of caries removal, the success of the treatment depends on placing hermetically sealed restorations and appropriate case selection. (Ricketts et al, 2013; Kidd et al, 2004; Thompson et al, 2008).

\section{Restorations after Selective Excavation:-}

Mertz-Fairhurst et al (1998) concluded that 'the bonded and sealed composite restorations placed over frank cavitated lesions arrested the clinical progress of these lesions for 10 years'. Foley et al (2004) concluded that the restorations placed in teeth treated with GIC alone after partial caries removal exhibited a durability and effectiveness comparable with those placed in teeth that had undergone complete caries removal. Fairbourn et al.(1990) utilized pulp capping agents after partial excavation of infected dentin such as zinc oxide eugenol, with or without a calcium hydroxide base. Though clinical studies have suggested good prognosis of restorations of both composite and glass ionomer restorations after partial caries excavation, in-vitro studies have proven otherwise. Various in-vitro studies have concluded the low bond strength of caries infected dentin to glass ionomer restorations, when compared to restorations performed after complete caries excavations.(Palma-Dibb et al.,2003; Yoshiyama et al., 2003)

Schewendicke et al. (2014) through the results of their in-vitro study, concluded that the marginal integrity and micro leakage did not vary significantly in composite restorations performed after selective and complete caries excavation. In another in-vitro study, Schewendicke et al (2015) assessed the influence of bonding systems and composites in selectively excavated teeth restored using composite restorations and concluded that the marginal integrity was influenced by the bonding system, but not by the type of composite used. The fourth generation etch and rinse bonding system and a two-step self-etch bonding system showed better results.

Thompson et al (2008) discussed that while clinicians may find pulpal floor gaps more often when deep caries remains because of composite's inability to bond completely to caries-infected and caries-affected dentin; the chance of postoperative hypersensitivity might be reduced because the pulp is protected from fluid flow in the tubules by the low-permeability zone in deep infected dentin. Thus, we can conclude that carious dentin should be removed completely from preparation walls, but selectively from the pulpal floor or axial wall.

\section{Conclusion:-}

Selective excavation in deep carious lesions is known to reduce the incidence of pulp exposure in asymptomatic, vital primary as well as permanent teeth. Thus, these techniques show clinical advantage over complete caries removal in the management of dentinal caries. The available studies provide insufficient evidence to ascertain whether or not there was a difference in signs and symptoms of pulp disease between partial caries removal and complete caries removal. The longevity and clinical durability of restorations performed after partial caries excavation still remains unclear, due to lack of sufficient evidence. Most of the studies have a short term follow-up, thus there is a clear need of long term clinical trials to assess the most effective intervention in management of deep carious lesions. 


\section{References:-}

1. Bjorndal L. (2008): Indirect pulp therapy and stepwise excavation. J Endod., 34:29-33.

2. Fairbourn DR, Charbeneau GT, Loesche WJ. (1990): Effect of improved Dycal and IRM on bacteria in deep carious lesions. J Am Dent Assoc., 100(4):547-552.

3. Foley J, Evans D, Blackwell A. (2004): Partial caries removal and cariostatic materials in carious primary molar teeth: a randomised controlled clinical trial. Br Dent J., 197(11):697-701.

4. Fejerskov O, Nyvad B, Kidd EA. (2015): Pathology of Dental Caries. In: Fejerskov O, Nyvad B, Kidd EAM (eds) Dental caries: the disease and its clinical management. 3rd ed. Oxford (UK): Wiley Blackwell, pp. 7-9.

5. Franzon R, Guimaraes LF, Magalhaes CE, Haas AN, Araujo FB. (2014): Outcomes of one-step incomplete and complete excavation in primary teeth: a 24-month randomized controlled trial. Caries Res., 48:376-383Gruythuysen RJ, van Strijp AJ, Wu MK. (2010): Long-term survival of indirect pulp treatment performed in primary and permanent teeth with clinically diagnosed deep carious lesions. J Endod., 36(9):1490-1493.

6. Handelman SL, Washburn F, Wopperer P. (1976): Two-year report of sealant effect on bacteria in dental caries. J Am Dent Assoc.,93(5):967-70.

7. Hesse D, Bonifacio CC, Mendes FM, Braga MM, Imparato JC, Raggio DP. (2014): Sealing versus partial caries removal in primary molars: a randomized clinical trial. BMC oral health.,14(1):1.

8. Innes NP, Frencken JE, Bjørndal L, Maltz M, Manton DJ, Ricketts D, Van Landuyt K, Banerjee A, Campus G, Doméjean S, Fontana M, Leal S, Lo E, Machiulskiene V, Schulte A, Splieth C, Zandona A, Schwendicke F. (2016): Managing carious lesions: consensus recommendations on terminology. Adv Dent Res., 28(2):49-57.

9. Kidd EA. (2004): How 'clean' must a cavity be before restoration? Caries Res., 38 (3):305-313.

10. Lula EC, Monteiro-Neto V, Alves CM, Ribeiro CC.(2009): Microbiological analysis after complete or partial removal of carious dentin in primary teeth: a randomized clinical trial. Caries Res., 43(5):354-8.

11. Lula EC, Almeida Jr LJ, Alves CM, Monteiro-Neto V, Ribeiro CC.(2011): Partial caries removal in primary teeth: association of clinical parameters with microbiological status. Caries Res., 45(3):275-80.

12. Maltz M, Jardim JJ, Mestrinho HD, Yamaguti PM, Podesta K, Moura MS, de Paula LM.(2013):Partial removal of carious dentine: a multicentre randomized controlled trial and 18-month follow-up results. Caries Res.,47: 103-109.

13. Mertz-Fairhurst EJ, Call-Smith KM, Shuster GS, et al. (1987): Clinical performance of sealed compositerestorations placed over caries compared with sealed and unsealed amalgam restorations. J Am Dent Assoc., 115(5):689-694.

14. Mertz-Fairhurst EJ, Curtis JW, Ergle JW, Rueggeberg FA, Adair SM. (1998): Ultraconservative and cariostatic sealed restorations: results at year 10. J Am Dent Assoc., 129(1):55-66.

15. Murray PE, Smith AJ, Windsor LJ, Mjor IA. (2003): Remaining dentine thickness and human pulp responses. Int Endod J.,36(1):33-43.

16. Palma-Dibb RG, de Castro CG, Ramos RP, Chimello DT, Chinelatti MA.(2003): Bond strength of glass ionomer cements to caries-affected dentin. J Adhes Dent.,25(1):57-62.

17. Phonghanyudh A, Phantumvanit P, Songpaisan Y, Petersen PE.Clinical evaluation of three caries removal approaches in primary teeth: a randomised controlled trial. Community Dent Health. 2012; 29 (2):173-8.

18. Ribeiro CC, Baratieri LN, Perdigao J, Baratieri NM, Ritter AV.(1999): A clinical, radiographic, and scanning electron microscopic evaluation of adhesive restorations on carious dentin in primary teeth. Quintessence Int.,30(9): 591-9.

19. Ribeiro CCC, Lula ECO, da Costa RCN, Nunes AMM. (2012): Rationale for the Partial Removal of Carious Tissue in Primary Teeth. Pediatr Dent., 34:39-41.

20. Ricketts D, Lamont T, Innes NP, Kidd E, Clarkson JE.(2013):Operative caries management in adults and children.Cochrane Database Syst Rev., 3:CD003808. doi: 10.1002/14651858.CD003808.pub3.

21. Thompson V, Craig RG, Curro FA.(2008): Treatment of deep carious lesions by complete excavation or partial removal: A critical review. J Am Dent Assoc., 139(6): 705-712.

22. SchwendickeF,Kern M,Blunck U,Dorfer C, DrenckJ,Paris S. (2014): Marginal integrity and secondary caries of selectively excavated teeth in vitro.J Dent.,42 (10):1261-1268.

23. SchwendickeF,Kern M,Dorfer C,Kleemann- Lupkes J, Paris S, Blunck U.(2015): Influence of using different bonding systems and composites on the margin integrity and the mechanical properties of selectively excavated teeth in vitro. J. Dent., 43(3):327-34.

24. Schwendicke F, Schweigel H, Petrou MA, Santamaria R, Hopfenmüller W, Finke C, Paris S. (2015): Selective or stepwise removal of deep caries in deciduous molars: study protocol for a randomized controlled trial. Trials., 16:11. doi: 10.1186/s13063-014-0525-9.

25. van Bochove JA, van Amerongen WE. (2006): The influence of restorative treatment approaches and the use of local analgesia, on the children's discomfort. Eur Arch Paediatr Dent., 7(1):11-16.

26. Yoshiyama M, Tay FR, Torii Y, et al.(2003): Resin adhesion to carious dentin. Am J Dent.,16(1):47-52. 